\title{
DEVELOPMENT OF PHONEMICALLY BALANCED WORD LISTS FOR ADULTS IN THE KANNADA LANGUAGE
}

\author{
Puttabasappa Manjula, Jawahar Antony, Keelara Shivaraju Sharath Kumar, \\ Chinnaraj Geetha
}

Department of Audiology, All India Institute of Speech and Hearing, Mysore, India

Corresponding author: Chinnaraj Geetha, Department of Audiology, All India Institute of Speech and Hearing, Mysore, India, e-mail: geethamysore.cs@gmail.com

\begin{abstract}
Background: Standard word lists are required to assess an individual's level of speech understanding. The material should comprise a number of lists and has to be in the listener's native language. The aim of the present study was to develop and standardize a set of phonemically balanced word lists for adults in the Kannada language.

Material and methods: Exactly 1200 bisyllabic Kannada words were collected from various sources and evaluated for familiarity. The words that were familiar ( 820 of them) were assessed for equivalency at $-3 \mathrm{~dB}$ signal-to-noise ratio (SNR) to make sure that the words in the lists were of equal difficulty. Equivalency across the word lists were assessed, in quiet at four sensation levels, on 65 participants with normal hearing. Equivalency was also assessed on 100 participants with normal hearing in noise at $-3 \mathrm{~dB}$ SNR.

Results: The assessment of word equivalency revealed that 769 words had a score of around $50 \%$ identification at $-3 \mathrm{~dB}$ SNR. These words were then used to construct 25 test lists each containing 25 words. Except for List 5, all other word lists were equivalent in quiet. The performance intensity function for phonemically balanced words in quiet was derived at 4 SLs for all the other 24 lists. Assessment of list equivalency in noise revealed that Lists 1, 4, 5, and 12 were significantly different from the other lists. After removing these four lists, the mean word recognition score was $46.04 \%$ (raw score) at $-3 \mathrm{~dB}$ SNR in 100 individuals with normal hearing sensitivity.
\end{abstract}

Conclusions: The standardized 24 word lists in quiet and 21 word lists in noise can be used for adults in routine speech identification testing, assessment of hearing aid benefits, and for research that requires multiple word lists.

Key words: word lists • word recognition scores • equivalence $\bullet$ Kannada

\section{ELABORACIÓN DE LISTADOS DE PALABRAS FONÉTICAMENTE EQUILIBRADAS EN EL IDIOMA KANNADA PARA ADULTOS}

\section{Resumen}

Introducción: Para poder evaluar de forma individual el grado del entendimiento del habla, se necesitan los listados estándar de palabras. El conjunto debe incluir un número determinado de listados de palabras en la lengua materna del oyente. El objetivo del estudio es elaborar y estandarizar el conjunto de listados de palabras fonéticamente equilibradas para adultos en el idioma kannada.

\footnotetext{
Métodos y materiales: En base a diversas fuentes, se recogieron 1200 palabras de dos silabas en el idioma kannada y a continuación fueron analizadas con respecto a sus similitudes. Las palabras que fueron consideradas similares (820 de 1200) fueron objeto de la valoración de la equivalencia para la relación señal/ruido (SNR) igual a $3 \mathrm{~dB}$, para asegurarse, de que cada listado de palabras presentaba el mismo grado de dificultad. La equivalencia entre los listados de palabras fue valorada en los condiciones de silencio para cuatro niveles de señal, en un grupo de 65 personas con una audición normal. La equivalencia fue también valorada para 100 personas con una audición normal en condiciones de ruido para $\mathrm{SNR}=3 \mathrm{~dB}$.

Resultados: El estudio de la equivalencia de las palabras ha demostrado, que para 769 palabras se consiguió el resultado de un $50 \%$ del entendimiento del habla para $\mathrm{SNR}=3 \mathrm{~dB}$. Estas palabras fueron utilizadas para crear 25 listados de palabras, cada una compuesto de 25 palabras. Excepto el listado 5, todos los demás listados fueron equilibrados en los condiciones de silencio. Las curvas de articulación (performance intensity function) fueron diseñadas para cuatro niveles de señal para todos los 24 listados. La valoración de la equivalencia en el ruido ha demostrado que los listados 1, 4, 5 y 12 se diferencian de una forma considerable de los demás. Después de su eliminación, el resultado del reconocimiento del habla fue de 46,04\% (raw score) para el $\mathrm{SNR}=3 \mathrm{~dB}$ determinado para 100 personas con una audición normal.
} 
Conclusiones: 24 listados estandarizados de palabras para las condiciones de "silencio" y 21 listados para la condición de "ruido" pueden ser utilizados en adultos para una valoración rutinaria de la discriminación del habla, para la evaluación del beneficio de implantar prótesis auditivas y para los estudios científicos que precisen de varios listados de palabras.

Palabras clave: listados de palabras • reconocimiento del habla • equivalencia • idioma kannada

\section{ФОНЕТИЧЕСКАЯ РАЗРАБОТКА СБАЛАНСИРОВАННЫХ СПИСКОВ СЛОВ НА ЯЗЫКЕ КАННАДА ДЛЯ ВЗРОСЛЫХ}

\section{Изложение}

Введение: Для оценки индивидуальной степени понимания речи нужны стандартные списки слов. Комплект должен содержать определенное количество списков слов на родном языке слушателя. Целью исследования является разработка и стандартизация комплекта фонетически сбалансированных списков слов для взрослых людей на языке каннада.

Методы и материал: Из разных источников были собраны 1200 двуслоговых слов на языке каннада и подвержены анализу, принимая во внимание подобия. Слова, которые были признаны подобными (820 из них) были подвержены оценке эквивалентности для соотношения сигнала к шуму(SNR), равному 3 дБ в целях убедиться, что каждый список слов имеет такую самую степень сложности. Сбалансированность между списками слов была оценена в условиях тишины для четырех уровней сигнала, в группе из 65 человек с правильным слухом. Сбалансированность была также оценена для 100 человек с нормальным слухом в условиях шума для SNR=3 дБ.

Результаты: Оценка сбалансированности слов показала, что для 769 слов получен результат ок. 50\% понимания речи для $\mathrm{SNR}=3 \mathrm{~dB}$. Эти слова были использованы для создания 25 списков слов, каждый из которых состоял из 25 слов. За исключением списка 5 все остальные списки были сбалансированы в условиях тишины. Артикуляционные кривые (performance intensity function) были определены для четырех уровней сигнала для всех 24 списков. Оценка сбалансированности в шуме показала, что списки 1, 4, 5 и 12 существенно отличаются от остальных. После их удаления средний результат распознавания речи составил 46,04\% (raw score) для $\mathrm{SNR}=3 \mathrm{~dB}$, определенный для 100 человек с правильным слухом.

Выводы: Стандартизированные 24 списки слов для условий "тишины" и 21 список для условий "в шуме" могут быть использованы у взрослых для рутинной оценки дискриминации речи, оценки пользы от протезирования слуха и научных исследований, требующих множества списков слов.

Ключевые слова: списки слов, распознавание речи, эквивалентность, язык каннада

\section{OPRACOWANIE FONETYCZNIE ZBALANSOWANYCH LIST SŁOWNYCH W JĘZYKU KANNADA DLA OSÓB DOROSŁYCH}

\section{Streszczenie}

Wprowadzenie: Do oceny indywidualnego stopnia rozumienia mowy potrzebne są standardowe listy słowne. Zestaw powinien zawierać określoną liczbę list słownych w ojczystym języku słuchacza. Celem badania jest opracowanie i standaryzacja zestawu fonetycznie zbalansowanych list słownych dla osób dorosłych w języku kannada.

Metody i materiał: Z różnych źródeł zebrano 1200 dwusylabowych słów w języku kannada i poddano je analizie pod kątem podobieństw. Słowa, które zostały uznane za podobne $(820 \mathrm{z}$ nich) zostały poddane ocenie ekwiwalentności dla stosunku sygnału do szumu (SNR) równemu $3 \mathrm{~dB}$, w celu upewnienia się, iż każda lista słowna ma ten sam stopień trudności. Zrównoważenie pomiędzy listami słownymi zostało ocenione w warunkach ciszy dla czterech poziomów sygnału, w grupie 65 osób ze słuchem prawidłowym. Zrównoważenie było także ocenione dla 100 osób z normalnym słuchem w warunkach szumu dla $\mathrm{SNR}=3 \mathrm{~dB}$.

Wyniki: Ocena zrównoważenia słów wykazała, że dla 769 słów uzyskano wynik ok. 50\% rozumienia mowy dla SNR=3 dB. Słowa te zostały użyte do stworzenia 25 list słownych, każda składająca się z 25 słów. Za wyjątkiem listy 5, wszystkie pozostałe listy były zrównoważone w warunkach ciszy. Krzywe artykulacyjne (performance intensity function) zostały wyznaczone dla czterech poziomów sygnału dla wszystkich 24 list. Ocena zrównoważenia w szumie wykazała, że listy 1, 4, 5 i 12 różnią się w sposób istotny od reszty. Po ich usunięciu, średni wynik rozpoznawania mowy wyniósł 46,04\% (raw score) dla SNR=3 dB wyznaczony dla 100 osób ze słuchem prawidłowym. 
Wnioski: Wystandaryzowane 24 listy wyrazowe dla warunków „ciszy” i 21 list dla warunku „w szumie” mogą być użyte u osób dorosłych dla rutynowej oceny dyskryminacji mowy, oceny zysku z protezowania słuchu i badań naukowych wymagających wielu list słownych.

Słowa kluczowe: listy słowne • rozpoznawanie mowy • ekwiwalencja • język kannada

\section{Background}

Speech tests provide valuable information regarding how well the auditory system performs in real world situations; they also can quantify the benefits provided by hearing devices. Speech tests therefore form an important part of routine audiological evaluation $[1,2]$.The choice of material used in speech audiometry ranges from simple nonsense syllables to sentences and depends on the purpose of the test, the age of the listener, and the auditory or listening abilities of the subject. Use of nonsense syllables (which at one time was the standard test material) rules out effects due to prior linguistic knowledge and helps in examining phonetic errors. However, Tyler [3] is of the opinion that use of nonsense syllables does not have face validity as they do not represent natural speech.

On the other hand, according to Martin and Clark [4], sentences contain contextual cues and are therefore expected to have better predictive validity than use of single words. Co-articulation as well as temporal aspects of speech can be assessed with sentence material. Nevertheless, these materials take longer to administer, and an individual's memory can affect their performance.

Although there is a wide variety of speech material such as nonsense syllables [5] or sentences [6], word lists remain the most commonly used material as there is a fair amount of balance between face validity and redundancy when compared to nonsense syllables and sentences. The most common material for speech recognition testing is monosyllabic words. Many sets of monosyllabic material are available in the English language, among them being the word lists of the Central Institute of the Deaf (CID W-22) and Northwestern University (NU-6).

India has several regional languages spoken in different parts of the country. Our institution is in Karnataka state in southern India where Kannada is the official language. Even though service seekers come from all over India, the majority of them speak Kannada. The fact that speech test material must be in the native language mandates use of Kannada word lists.

Phonemically balanced word lists for adults in Kannada have been developed by Yathiraj and Vijayalakshmi [7]; this work contains eight phonemically balanced bisyllabic word lists of 25 words each. The list equivalency has been assessed on 100 listeners with normal hearing sensitivity. The lists are used for routine hearing and hearing aid evaluation of Kannada speaking listeners. Although the lists are adequate for routine diagnostic hearing/hearing aid evaluation, for research purposes the limited number of word lists will affect results due to familiarization. In addition, practice/learning effects are associated with randomization and re-use of the same items. This prevents measurement and comparison of performance in multiple experimental or clinical conditions.
Further, improvements in hearing device technology have increased the number of features in a hearing device. When these features or parameters have to be evaluated and compared on a number of conditions, a large number of such lists are mandatory. Thus, the aim of the present study was to develop a larger number of bisyllabic word lists for evaluating hearing or hearing aid features. Bisyllabic words were chosen as there are very few meaningful monosyllabic words in Kannada: in fact there are not enough monosyllabic words to form even a single word list. The aim of the present study was to develop multiple word lists, so bisyllabic words were chosen.

\section{Material and methods}

The current study was carried out in two phases. Phase I consisted of development of the word lists, and Phase II was standardization of the lists. In Phase I, a pool of 1200 bisyllabic Kannada words was collected from various sources such as text books, a dictionary, magazines, and from a corpus developed by the Central Institute of Indian Language. Words representing proper nouns or related to politics or war were not considered.

The 1200 words were then rated for familiarity. For this, 15 native speakers of Kannada rated every word using a 5-point rating scale, with 5 for most familiar; 4 for familiar; 3 for familiar but not used every day; 2 for not familiar; and 1 for unknown. All the the raters had completed at least the $10^{\text {th }}$ class of education. Reponses from all individuals were compiled and words that were rated as 5 , 4 , or 3 by at least $80 \%$ of the raters were considered for the lists. Out of 1200 words, 820 were selected based on this criterion.

All the selected words were audio recorded by a female native speaker of Kannada. The speaker was instructed to pronounce the words in a natural, clear manner with neutral intonation, while maintaining constant vocal effort. The recording was done in a quiet acoustically treated room. The speech material was recorded using the Computerized Speech Lab (CSL) system with a high fidelity microphone placed $10 \mathrm{~cm}$ from the speaker's mouth. The speech waveforms were digitized with a 16 bit A/D converter at a sampling frequency of $44,100 \mathrm{~Hz}$.

\section{Generation of noise}

Equivalency of the material is an important issue that needs to be addressed whenever test materials for speech audiometry are being developed. Generally, test materials are developed under quiet conditions [8-12]. However, it has also been shown that if word recognition testing is done in the presence of background noise, list equivalency does not remain the same [13-18]. Furthermore, under quiet conditions one can expect to see a ceiling effect when the lists are administered on individuals with 
normal hearing sensitivity, an effect that might obscure inter-list equivalency.

Noise used for the testing was generated in such a way that it represented the long-term average spectrum of the speech stimulus, i.e., words, used in the present study. This was done by extracting the long-term average speech spectrum (LTASS) of all the words using MATLAB software (version 7.8.0.347). White noise was filtered to mimic the extracted long-term LTASS. The recorded words were then mixed with this noise at $-5 \mathrm{~dB},-3 \mathrm{~dB}, 0 \mathrm{~dB}$, and $+3 \mathrm{~dB}$ SNR.

\section{Test of equality between words}

To ensure that all the words being used to construct the lists were of equal difficulty, the 820 words previously selected as familiar were presented in the presence of noise at different SNRs to a group of 20 participants with normal hearing thresholds. All participants included at this step and in later steps underwent routine pure-tone audiometry and immittance screening. They all had pure tone air-conduction and bone-conduction thresholds within 15 $\mathrm{dB} H \mathrm{HL}$ at $0.25,0.5,1,2,4$, and $8 \mathrm{kHz}$ and passed immittance screening.

The SNRs considered were $-5 \mathrm{~dB},-3 \mathrm{~dB}, 0 \mathrm{~dB}$, and $+3 \mathrm{~dB}$ SNR. The words were routed through a personal computer and delivered through Sennheiser HDA 200 headphones via a calibrated audiometer. All the words at each SNR were administered to five individuals at their most comfortable level. Different individuals were considered for each SNR (5 participants at each SNR) making a total of 20 participants. The words were presented monaurally to either left or right ear randomly. All participants were instructed to repeat the words presented. The SNR at which an average $50 \%$ response was obtained was considered for further evaluation. Again at the same SNR (i.e., $-3 \mathrm{~dB}$ SNR), all the words were administered to 10 different individuals having normal hearing. The responses for all the words were then compiled and only those words that were repeated correctly by $40-60 \%$ of the participants were finally used to construct the 25 word lists. This procedure, which is similar to SNR-50, ensured that only words of moderate difficulty were taken and excluded words that were either very easy ( $>60 \%$ of individuals repeated the word correctly) or very difficult $(<40 \%)$.

In this way, 25 lists of bisyllabic words were constructed, with each list having 25 words. The words were balanced phonemically based on the frequency of occurrence of the phonemes in the Kannada language [19]. The frequency of occurrence of the phonemes in Kannada as given by Ramakrishna et al. [19] was first noted and tentative word lists formed. It was ensured that the frequency of occurrence of each phoneme in each list matched the frequency provided by Ramakrishna et al. [19].

\section{Standardization of the word lists in quiet}

The constructed word lists were presented in quiet to 65 individuals with normal hearing sensitivity, with mean age of 26.3 years and range 18 years to 40 years. None of these 65 participants were a part of any of the previous steps. A dual channel audiometer (GSI 61) coupled to acoustically matched TDH 39 headphones housed in MX-41 AR ear cushions and a B-71 bone vibrator were used to estimate pure tone hearing threshold, speech recognition threshold, and speech identification score. A calibrated middle ear analyzer (GSI Tympstar) was used to obtain a tympanogram and acoustic reflex threshold. The test stimulus was presented using a personal computer and delivered through Sennheiser HDA 200 headphones via the calibrated audiometer.

Pure tone air-conduction thresholds for each participant were established in octave frequencies from $250 \mathrm{~Hz}$ to $8000 \mathrm{~Hz}$, using the modified Hughson and Westlake method [20]. Bone-conduction thresholds were also established using the same method for octave frequencies from $250 \mathrm{~Hz}$ to $4000 \mathrm{~Hz}$.

The tympanometric measurements were done using a 226 $\mathrm{Hz}$ probe tone at 85 SPL to evaluate the status of the middle ear. For acoustic reflex measurements, reflex eliciting tones at 500,1000,2000, and $4000 \mathrm{~Hz}$ were presented both ipsilaterally and contralaterally to confirm the normal status of the middle ear.

\section{Administration of developed word lists in quiet}

Subjects were administered with all the 25 lists in quiet. The words were routed through a personal computer and delivered monaurally through Sennheiser HDA 200 headphones from a calibrated audiometer. The words were presented at $40 \mathrm{~dB}$ SL (ref. PTA) to 65 participants with normal hearing sensitivity. The participants were instructed to repeat the words and the responses were recorded on a scoring sheet. Every correct response was given a score of 1 and a score of 0 was given for incorrect responses or failure to repeat the word. The word lists were also presented to 20 individuals with normal hearing sensitivity out of the 65 participants. This was done at $0 \mathrm{~dB} \mathrm{SL}, 10 \mathrm{~dB}$ SL, and $20 \mathrm{~dB}$ SL in order to obtain a psychometric function of performance with the word lists across intensity levels, i.e., the performance intensity (PI) function for phonemically balanced words (PB). The order of presentation of the word lists was randomized in order to avoid an order effect. In order to avoid a practice effect, the word list was first presented at $0 \mathrm{~dB}$ SL and then at $10 \mathrm{~dB}$ SL. The testing was done at $20 \mathrm{~dB}$ SL after a break of at least 5 days.

Standardization on participants with normal hearing in noise

The data were collected from native speakers of Kannada, i.e., adult listeners in the age range from 18 to 55 years with a mean age of 33.8 years. The present study incorporated a different group of 100 individuals with normal hearing sensitivity and middle ear function. All the evaluations were carried out in an air-conditioned, well illuminated, and acoustically treated double room with the same equipment, procedure, and criteria for selection of participants as in the previous section.

\section{Administration of developed word lists}

The group of 100 individuals with normal hearing sensitivity were administered with all the 25 word lists in the 
Table 1. Mean and SD of word recognition scores (max. score $=25)$ for 25 lists in individuals with normal hearing $(N=65)$

\begin{tabular}{|c|c|c|c|c|c|c|c|c|}
\hline & Mean & SD & & Mean & SD & & Mean & SD \\
\hline List 1 & 24.73 & 0.69 & List 11 & 24.41 & 0.67 & List 21 & 23.88 & 2.72 \\
\hline List 2 & 24.56 & 0.69 & List 12 & 24.65 & 0.57 & List 22 & 24.56 & 0.76 \\
\hline List 3 & 24.33 & 0.87 & List 13 & 24.51 & 0.85 & List 23 & 24.58 & 0.53 \\
\hline List 4 & 24.61 & 0.82 & List 14 & 24.56 & 0.78 & List 24 & 24.50 & 1.08 \\
\hline List 5 & 23.96 & 1.00 & List 15 & 24.41 & 0.88 & List 25 & 24.38 & 0.95 \\
\hline List 6 & 24.15 & 0.95 & List 16 & 24.55 & 0.85 & & & \\
\hline List 7 & 24.53 & 0.70 & List 17 & 24.45 & 0.89 & & & \\
\hline List 8 & 24.56 & 0.81 & List 18 & 24.33 & 0.95 & & & \\
\hline List 9 & 24.65 & 0.79 & List 19 & 24.56 & 0.56 & & & \\
\hline List 10 & 24.46 & 0.87 & List 20 & 24.15 & 3.00 & & & \\
\hline
\end{tabular}

presence of noise at $-3 \mathrm{~dB}$ SNR. An SNR of $-3 \mathrm{~dB}$ was chosen because it yielded an average of $50 \%$ correct responses in a pilot study done to assess equivalency. The words were presented through a personal computer and routed from a calibrated audiometer to Sennheiser HDA 200 headphones in a double room test situation. The participants were instructed to repeat the words and the responses were recorded on a scoring sheet. All lists were administered at most comfortable level (MCL). Every correct response was given a score of 1 and a score of 0 was given for incorrect responses or failure to repeat a word. The maximum score was 25 for each list.

\section{Results}

In the present study, phonemically balanced word lists for adults in the Kannada language were developed. In Phase I, a total of 820 words were chosen, based on familiarity rating, from 1200 bisyllabic Kannada words. Word equivalency was also assessed at $-3 \mathrm{~dB}$ SNR, where 769 words had a score of around $50 \%$ identification at $-3 \mathrm{~dB}$ SNR.

These words were then used to construct 25 lists, each containing 25 words. Hence, the test included a total of 625 words at this stage through the process of phonemic balancing. The remaining 104 words were not accommodated in the word lists as phonemic balancing could not be achieved. Standardization of the word lists in quiet on 65 individuals with normal hearing sensitivity was done at $40 \mathrm{~dB}$ SL. Table 1 gives the mean and standard deviation (SD) of number of words correctly repeated for each of the 25 word lists.

Repeated measures ANOVA was carried out to see if there was any difference between the word lists. The test revealed that there was a significant difference in performance across the lists $[F(24,1416)=2.766, p<0.001]$ revealing a main effect of the lists. Hence, post-hoc Bonferroni pair-wise comparison was done to identify the list/s that differed significantly. The results revealed that only List 5 was significantly different from Lists 1, 2, 4, 7, 9, 12, 14, 19, 22,23 , and 24 as shown in Table 2 . Hence, it was inferred that the remaining 24 word lists can be used in quiet. The list that differed from the other lists (List 5) can be used as a practice list.

A psychometric curve was drawn for the mean scores obtained for each word list across the four SLs (Figure 1) and sigmoid curves were obtained for all 24 word lists. Figure 1 reveals that as the SL increases the percent correct scores also increase, and at around $40 \mathrm{~dB}$ SL a plateau is achieved.

Standardization of the word lists on 100 individuals with normal hearing sensitivity was done at $-3 \mathrm{~dB}$ SNR. Table 3 gives the mean and standard deviation (SD) of a number of words correctly repeated for each of the 25 word lists.

It can be observed from Table 3 that the mean word recognition score (WRS) does not vary much across the lists except for List 1, 7, and 12. The SD is also uniform across the lists except for List 5. To determine if the difficulty level was similar across lists or if there was any statistical difference across lists, the difference between each individual's score for each list and the listener's mean score was calculated to obtain modified mean scores. For a particular individual, a mean score was derived by averaging their scores for all the lists. Use of a modified mean score is one way of statistically comparing the scores between different lists [21]. Table 4 presents the mean and SD of these modified mean scores. Repeated measures ANOVA was done on these modified mean (MM) values to see if there was any difference between the lists.

It can be observed from Table 4 that the deviation from the average mean score and the SD $( \pm 2)$ for all the lists showed similar values. However, the repeated measures ANOVA revealed that there was a significant difference in performance across the lists $[\mathrm{F}(24,2376)=4.526, p<0.001]$, revealing a main effect of the lists. Hence, post-hoc Bonferroni pair-wise comparison was done to find out the lists that differed significantly. The results of the pair-wise comparison are given in Table 5. The results reveal that List 1 was significantly different from Lists 4, 21, 23, and 25. List 4 was significantly different from Lists $1,2,5,7$, 
Table 2. Bonferroni pair-wise comparison across 25 PB word lists in quiet

\begin{tabular}{|c|c|c|c|c|}
\hline List No. (A) & List No. (B) & $\begin{array}{l}\text { Mean difference } \\
\text { of scores (A-B) }\end{array}$ & Standard error & Significance (p) \\
\hline \multirow[t]{11}{*}{5} & 1 & $0.767^{\star *}$ & 0.141 & 0.000 \\
\hline & 2 & $0.600^{*}$ & 0.137 & 0.015 \\
\hline & 4 & $0.650^{*}$ & 0.154 & 0.025 \\
\hline & 7 & $0.567^{\star}$ & 0.139 & 0.043 \\
\hline & 9 & $0.683^{*}$ & 0.155 & 0.013 \\
\hline & 12 & $0.683^{* *}$ & 0.131 & 0.001 \\
\hline & 14 & $0.600^{*}$ & 0.124 & 0.003 \\
\hline & 19 & $0.600^{*}$ & 0.141 & 0.023 \\
\hline & 22 & $0.600^{* *}$ & 0.112 & 0.000 \\
\hline & 23 & $0.617^{\star}$ & 0.139 & 0.012 \\
\hline & 24 & $0.533^{*}$ & 0.115 & 0.006 \\
\hline
\end{tabular}

Note: ${ }^{*} p<0.05 ;{ }^{* *} p<0.001$.

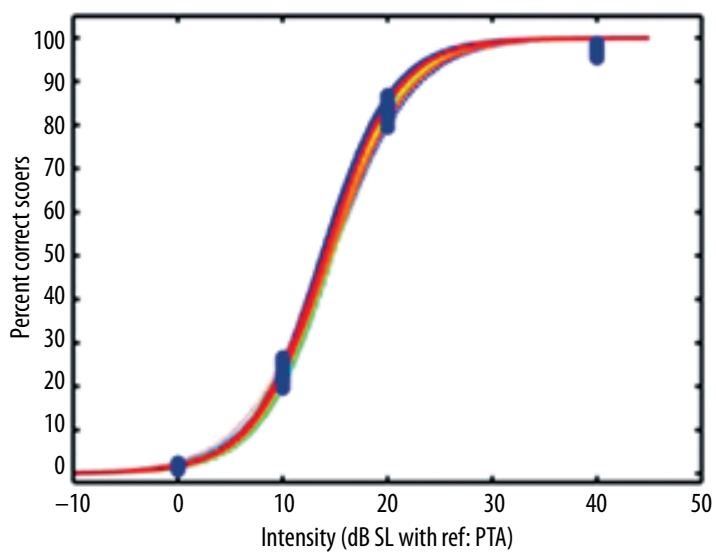

Figure 1. The PI-PB functions for the 24 PB word lists
$8,11,12,16,17$, and 22 . List 5 was significantly different from Lists 4, 13, 14, 18, 21, 23, 24, and 25. Finally, List 12 was different from Lists 4, 21, 23, and 25.

One of the requirements of word lists for speech audiometry is equivalency between lists. Hence, Lists $1,4,5$, and 12 were eliminated from the test for speech recognition. However, all the other 21 equivalent word lists were retained in the final test. The remaining four lists can be used as practice lists.

After removing Lists 1, 4, 5, and 12, the normative performance in noise (at $-3 \mathrm{~dB}$ SNR) of the 100 individuals with normal hearing sensitivity was 11.51 (mean value of the number of words correctly repeated), which is $46.04 \%$. In the present study, the WRS was $46 \%$ at $-3 \mathrm{~dB}$ SNR and $50 \%$ at an SNR higher than $-3 \mathrm{~dB}$. All the final 21 equivalent lists were renumbered and given as List 1 to List 21.

Table 3. Mean and SD of word recognition scores (max. score $=25)$ for 25 word lists in individuals with normal hearing $(N=100)$

\begin{tabular}{|c|c|c|c|c|c|c|c|c|}
\hline & \multicolumn{2}{|c|}{ WRS } & & \multicolumn{2}{|c|}{ WRS } & & \multicolumn{2}{|c|}{ WRS } \\
\hline & Mean & SD & & Mean & SD & & Mean & SD \\
\hline List 1 & 10.05 & 2.02 & List 11 & 10.31 & 1.78 & List 21 & 11.07 & 1.81 \\
\hline List 2 & 12.19 & 2.84 & List 12 & 12.64 & 2.06 & List 22 & 12.22 & 2.50 \\
\hline List 3 & 11.34 & 2.61 & List 13 & 11.22 & 2.37 & List 23 & 11.70 & 2.10 \\
\hline List 4 & 11.23 & 2.00 & List 14 & 11.70 & 1.81 & List 24 & 11.45 & 2.24 \\
\hline List 5 & 11.34 & 3.17 & List 15 & 11.70 & 2.24 & List 25 & 11.94 & 1.89 \\
\hline List 6 & 11.22 & 2.28 & List 16 & 12.24 & 2.21 & & & \\
\hline List 7 & 12.84 & 2.82 & List 17 & 10.64 & 2.16 & & & \\
\hline List 8 & 10.42 & 2.13 & List 18 & 11.30 & 1.96 & & & \\
\hline List 9 & 10.96 & 2.30 & List 19 & 11.78 & 2.47 & & & \\
\hline List 10 & 11.71 & 2.70 & List 20 & 11.81 & 1.86 & & & \\
\hline
\end{tabular}


Table 4. Average and SD of modified means (MM) of word recognition scores $(N=100)$

\begin{tabular}{|c|c|c|c|c|c|c|c|c|}
\hline & MM & SD & & MM & SD & & MM & SD \\
\hline List 1 & 1.60 & 0.99 & List 11 & 1.47 & 1.02 & List 21 & 1.10 & 0.71 \\
\hline List 2 & 1.40 & 1.13 & List 12 & 1.66 & 1.20 & List 22 & 1.47 & 1.08 \\
\hline List 3 & 1.28 & 0.77 & List 13 & 1.24 & 0.65 & List 23 & 1.07 & 0.81 \\
\hline List 4 & 0.91 & 0.73 & List 14 & 1.15 & 0.89 & List 24 & 1.14 & 1.03 \\
\hline List 5 & 1.70 & 0.90 & List 15 & 1.15 & 1.12 & List 25 & 1.07 & 0.94 \\
\hline List 6 & 1.29 & 0.89 & List 16 & 1.33 & 0.82 & & & \\
\hline List 7 & 1.65 & 1.52 & List 17 & 1.43 & 1.07 & & & \\
\hline List 8 & 1.40 & 0.99 & List 18 & 1.20 & 0.85 & & & \\
\hline List 9 & 1.26 & 0.87 & List 19 & 1.41 & 1.10 & & & \\
\hline List 10 & 1.32 & 1.14 & List 20 & 1.33 & 0.92 & & & \\
\hline
\end{tabular}

Table 5. Bonferroni pair-wise comparison across 25 word lists at $-3 \mathrm{~dB}$ SNR

\begin{tabular}{|c|c|c|c|c|}
\hline List No. (A) & List No. (B) & Mean difference (A-B) & Standard error & Significance (p) \\
\hline \multirow[t]{4}{*}{ List 1} & List 4 & $0.694^{\star *}$ & 0.128 & 0.000 \\
\hline & List 21 & $0.505^{*}$ & 0.128 & 0.044 \\
\hline & List 23 & $0.528^{*}$ & 0.123 & 0.012 \\
\hline & List 25 & $0.530^{*}$ & 0.133 & 0.041 \\
\hline \multirow[t]{10}{*}{ List 4} & List 1 & $-0.694^{* *}$ & 0.128 & 0.000 \\
\hline & List 2 & $-0.490^{\star}$ & 0.122 & 0.035 \\
\hline & List 5 & $-0.795^{\star *}$ & 0.117 & 0.000 \\
\hline & List 7 & $-0.740^{*}$ & 0.173 & 0.013 \\
\hline & List 8 & $-0.487^{* *}$ & 0.094 & 0.000 \\
\hline & List 11 & $-0.565^{\star *}$ & 0.115 & 0.001 \\
\hline & List 12 & $-0.749^{\star *}$ & 0.143 & 0.000 \\
\hline & List 16 & $-0.417^{*}$ & 0.105 & 0.038 \\
\hline & List 17 & $-0.523^{\star}$ & 0.129 & 0.030 \\
\hline & List 22 & $-0.557^{\star *}$ & 0.117 & 0.002 \\
\hline \multirow[t]{8}{*}{ List 5} & List 4 & $0.795^{\star *}$ & 0.117 & 0.000 \\
\hline & List 13 & $0.468^{*}$ & 0.110 & 0.014 \\
\hline & List 14 & $0.550^{* *}$ & 0.121 & 0.005 \\
\hline & List 18 & $0.500^{*}$ & 0.116 & 0.011 \\
\hline & List 21 & $0.606^{\star \star}$ & 0.104 & 0.000 \\
\hline & List 23 & $0.629^{* *}$ & 0.112 & 0.000 \\
\hline & List 24 & $0.562^{*}$ & 0.141 & 0.039 \\
\hline & List 25 & $0.631^{\star *}$ & 0.131 & 0.001 \\
\hline \multirow[t]{4}{*}{ List 12} & List 4 & $0.749^{\star *}$ & 0.143 & 0.000 \\
\hline & List 21 & $0.560^{\star *}$ & 0.121 & 0.003 \\
\hline & List 23 & $0.583^{\star \star}$ & 0.130 & 0.006 \\
\hline & List 25 & $0.586^{\star *}$ & 0.133 & 0.008 \\
\hline
\end{tabular}

Note: ${ }^{*} p<0.05 ;{ }^{* *} p<0.01$. 


\section{Discussion}

The present study involved selecting words from various sources in the Kannada language and assessing the familiarity of the words, since this greatly affects speech identification [22]. These familiar words were then subjected to equivalency assessment. The words that were familiar and equivalent were used to construct word lists. These lists were presented at $40 \mathrm{~dB}$ SL to 65 individuals with normal hearing sensitivity in quiet. Tillman and Carhart [8] have indicated that a test material should have many lists in order to avoid familiarization. In the present study, since 24 out of 25 word lists were not significantly different in terms of WRS, the 24 word lists were retained in the final test to be used in quiet.

The percentage of speech recognition scores obtained at 40 dB SL was around $98 \%$ for the 24 equivalent lists. Similar findings have been reported in the literature. In a study by Ullrich and Grimm [23], it was reported that individuals with normal hearing sensitivity obtained a maximum score of about $99.7 \%$ at MCL. Beattie and colleagues [24] obtained a speech discrimination score of approximately $95 \%$ at $32 \mathrm{~dB}$ SL for individuals with normal hearing sensitivity upon administration of CID W-22 and NU-6.

Out of the 25 word lists used for obtaining speech recognition scores in the presence of speech noise, 21 lists did not differ from each other. The mean speech recognition score of 21 lists (after removing Lists 1, 4, 5, and 12 ) in noise was 11.51 (46.04\%). Wilson and colleagues [25] compared speech recognition performance in speech spectrum noise using CID W-22, NU-6, and W-1 spondaic words. They found a score of $50 \%$ at an SNR of 1 $\mathrm{dB}$. This is comparable to the results found in the present study. In the present study, around $46 \%$ was obtained at $-3 \mathrm{~dB}$ SNR; a $50 \%$ score would be obtained at an SNR slightly higher than $-3 \mathrm{~dB}$. Hence, these 24 phonemically balanced (PB) word lists can be used in quiet, and $21 \mathrm{~PB}$ word lists can be used in noise conditions for Kannadaspeaking adults during routine speech identification testing. Assessment of the material's sensitivity to differences in speech identification ability across different degrees of hearing loss is being done.

\section{Conclusions}

Following the need for multiple phonemically balanced word lists for routine hearing and hearing aid evaluation in the Kannada language, multiple PB word lists for adults were developed and standardized. The word lists were equivalent in terms of level of difficulty, number of words, and phonemic balancing. These 24 Kannada word lists can be used on adults in routine speech identification testing and hearing aid evaluation, both for clinical and research purposes. All 24 lists can be administered for testing in quiet, while 21 can be used to test in noise.

\section{Acknowledgements}

The data used here is part of a project funded by the AIISH Research Fund. AIISH holds copyright of the test material. Interested readers may purchase the developed test from the Director, AIISH at director@aiishmysore.in. The authors wish to thank the Director and all the participants. We acknowledge Dr Vasanthalakshmi, Lecturer in Biostatistics, and Ms Jyothi S, Research Assistant, AIISH, Mysore, for their timely help.

\section{Conflict of interests: None}

\section{References:}

1. Thibodeau L. Audiology diagnosis. $2^{\text {nd }}$ ed. New York: Thieme Medical Publishers; 2000.

2. Gelfand SA. Essentials of audiology. $3^{\text {rd }}$ ed. New York: Thieme Medical Publishers; 2000.

3. Tyler RS. The use of speech perception tests in audiological rehabilitation: current and future research needs. J Rehab Res Dev, 1994; 27: 47-66.

4. Martin FN, Clark JG. Speech audiometry. $10^{\text {th }}$ ed. Boston: Allyn and Bacon; 2009.

5. Levitt H, Resnick SB. Speech reception by the hearing impaired: methods of testing and the development of new tests. Scan Audiol, 1978; 107(6): 130.

6. Kollmeier B, Wesselkamp M. Development and evaluation of German sentence tests for objective and subjective speech intelligibility assessment. J Acoust Soc Am, 1997; 102: 2412-21.

7. Yathiraj A, Vijayalakshmi CS. Phonemically balanced word list in Kannada. Developed in Department of Audiology 2005, AIISH, Mysore.

8. Tillman TW, Carhart R. An expanded test for speech discrimination utilizing CNC monosyllabic words. North Western University Auditory Test No. 6. In: Gelfand SA (eds), Essentials of Audiology ( $3^{\text {rd }}$ ed.), New York: Thieme Medical Publishers, 1966; 246.

9. Hurley RM, Sells JP. An abbreviated word recognition protocol based on item difficulty. Ear Hear, 2003; 24(2): 111-8.
10. Stockley KB, Green WB. Interlist equivalency of the Northwestern University Auditory Test No. 6 in quiet and noise with adult hearing-impaired individuals. J Am Acad Audiol, 2000; 11(2): 91-6.

11. Stuart A, Green WB, Phillips DP, Stenstrom R. List equivalency of the Northwestern University Auditory Test No. 6 in quiet and in continuous broad band noise. J Speech Lang Path Audiol, 1994; 18(2): 121-5.

12. Wilson RH, Coley KE, Haenel JL, Browning KM. Northwestern University Auditory Test No. 6: normative and comparative intelligibility functions. J Am Audiol Soc, 1976; 1: 221-8.

13. Chermak GD, Pederson CM, Bendel RB. Equivalent forms and split-half reliability of the NU-CHIPS in noise. J Speech Hear Dis, 1984; 49: 196-201.

14. Chermak GD, Wagner DP, Bendel RB. Interlist equivalence of the word intelligibility by picture identification test administered in broad-band noise. Audiol, 1988;27(6): 324-33.

15. Gengel RW, Miller L, Rosenthal E. Between and within listener variability in response to CID W-22 presented in noise. Ear Hear, 1981; 2(2): 78-81.

16. Loven EC, Hawkins DB. Interlist equivalency of the CID W-22 word lists presented in quiet and in noise. Ear Hear, 1983; 4: 91-7. 
17. Rippy JV, Dancer JE, Pittenger JB. List equivalency of the CID everyday sentences (Harris revision) under three signal-tonoise ratios. Ear Hear, 1983; 4(5): 251-4.

18. Schubert GW, Stenhjem BW. A reliability study of the Goldman-Fristoe-Woodcock test of auditory discrimination with learning disabled children. Acta Symbol, 1978; 7(9): 43-56.

19. Ramakrishna BS, Nair KK, Chiplunkar VN, Atal BS, Ramachandran V, Subramanian R. Some aspect of relative efficiencies of Indian languages, 1962. Indian Institute of Science, Bangalore.

20. Carhart R, Jerger JF. Preferred method for clinical determination of pure-tone thresholds. J Speech Hear Dis, 1959; 24: $330-45$.

21. Spahr AJ, Dorman MF, Litvak LM, Van Wie S, Gifford RH, Loizou PC et al. Development and validation of the AzBio sentence lists. Ear Hear, 2012; 33(1): 112-7.
22. Owens E. Intelligibility of words varying in familiarity. J Speech Hear Res, 1961; 4: 113-29.

23. Ullrich K, Grimm D. Most comfortable listening level presentation versus maximum discrimination for word discrimination material. Audiol, 1976; 15: 338-47.

24. Beattie RC, Edgerton BJ, Svihovec D. A comparison of Auditec St. Louis cassette recordings of NU-6 and CID W-22 on normal hearing population. J Speech Hear Dis, 1977; 42: 60-4.

25. Wilson RH, McArdle R, Roberts HA. Comparison of recognition performances in speech-spectrum noise by listeners with normal hearing on PB-50, CID W-22, NU-6, W-1 spondaic words, and monosyllabic digits spoken by the same speaker. J Am Acad Audiol, 2008; 19(6): 496-506. 